\title{
日常生活における時間単位の心理的親近性
}

\author{
一対比較法を用いた心理尺度の構成 \\ ○森田麻登 ${ }^{1} \cdot$ 森島泰則 $^{2}$ \\ ( ${ }^{1}$ 植草学園大学・ 2 国際基督教大学) \\ キーワード：時間単位，心理的親近性，一対比較法
}

\section{Psychological familiarity of time unit in daily life Asato MORITA $^{1}$ and Yasunori MORISHIMA ${ }^{2}$ \\ ( ${ }^{1}$ Uekusa Gakuen University, ${ }^{2}$ International Christian University)}

Key Words: time unit, psychological familiarity, paired comparison

\section{目 的}

我々は，日常生活の中で時間を意識して過ごしている。例 えば， 1 年後には博士論文を提出すると目標を立てて，指導 教員に日々の進捗状況を相談する一方で, 1 力月後の旅行の 計画を立てて期待に胸はずませたり， 1 週間後の授業の準備 に頭を悩ませたり，明日の食事のメニューを考えたり，今日 の帰りの電車の時間を気にしたり，1 時間後の会議のことを 考えて憂䍌になったり，目の前の作成途中の資料の完成まで の時間を見積もったり，このように，生活のあちこちで，年 単位, 週単位, 時間単位, 分単位, 秒単位で時間を意識して いるのである。また，時間の感じ方も様々な状況やパーソナ リテイで異なっていることが知られている（森田, 2012)。「楽 しい時間は短く感じ, 退屈や苦痛に感じる時間は長く感じる」 という経験は誰でも思い当たることがあるだろう。Meck (2005) は，ある出来事が起きてから，どのくらいの速さで時間が過 ぎているのか，あるいは，どのくらいの時間が経ったのかと いう内的な経験を心理的時間 (psychological time) または, 主観的時間（subjective time）と定義した。近年，心理的時 間研究は心理学分野で注目されている。

本研究では, 健康な成人を対象に, 普段の生活の中で意識 している様々な時間単位について，その心理的な身近さ（心 理的親近性）がどのような関係になっているのかを把握する ことを目的とした。用いる時間単位は，「年」「月」「曜日」「日」 「時」「分」「秒」の 7 つであった。各時間単位について，一 対比較法により，心理尺度值を算出することとした。

\section{方 法}

研究参加者 一般成人 389 名（男性 192 名，女性 197 名）が 参加した。平均年齢は，22.39 28.87 歳であった。

刺激「年」「月」「曜日」「日」「時」「分」「秒」の 7 つの時 間単位から 2 つずつを 1 対にして 21 項目作成し, これをラン ダムに上から 1 問目から 21 問目まで並べた回答用紙を作成し た。なお，順序効果を相殺するため，回答用紙は 2 つのバー ジョンを作成し，カウンターバランスをとった。

手続き 回答用紙を実験参加者に配布し, 実験参加者のペー スで回答してもらった。最初に実験の内容について説明し, インフォームドコンセントの後, 練習, 本番を行った。教示 は，「2つの時間単位が 1 対出てきます。この 2 つの単位は,

「年」「月」「曜日」「日」「時」「分」「秒」の 7 つです。この 2 つの時間について，あなたにとってより身近に感じる方を 丸で囲んでください。なかなか決まらない場合であっても， 必ずどちらか選んでください」であった。

データ分析 列刺激が行刺激よりも身近に感じられると判断 された度数を集計し，度数行列を作成した（対角の位置の度 数の和は, 判断度数 (N) と等しくなるようにした)。それぞ れのセルに対する選択確率を求めるため, 列ごとに度数の合 計值を算出し，各セルの度数を判断度数（N) で割って比率を
求め, 比率行列を作成した。刺激間の相対的距離を算出する ため, 比率行列の值をMicrosoft Excel の関数 “NORMSINV” を用いて計算し，尺度距離行列を作成した。尺度距離行列の 平均值を求め, 各時間単位の心理尺度值とした。

\section{結 果}

親近性の高い時間単位（身近な方）から，「時」「曜日」「日」 「分」「月」「年」「秒」となった。「時」「曜日」「日」は比較 的身近に感じられている一方で，「秒」と「年」の位置は他と 比べて大幅に尺度值が離れており, 身近でないと感じている ことが明らかになった。

\section{考 察}

本研究は, 時間単位についての心理尺度值を算出すること をねらい，健康な成人に対して，7つの時間単位を用いた心 理的親近性（身近さ）の一対比較を行った。その結果，「時」 や「曜日」を身近に感じ，「秒」や「年」については身近に感 じないという結果が明らかになった。

今回の研究参加者の多くは大学生, もしくは社会人や主婦 であり，授業，仕事，家事や育児などで忙しく日々を過ごし ていることが推察される。そのため, 日々の生活の中で最も 自分自身の行動の基準となりやすい単位を身近に感じていた のではないかと考えられる。一般的に日々の予定は「時」「曜 日」「日」「分」は欠かせない要素であろう。この時間単位を 常に意識していなければ，日常の “やる心゙きこと”をこなす ことはおそらく難しくなるであろう。このことは,「秒」や「年」 の身近さが低くなったこととも合致している。なぜならば,

「秒」や「年」は，日々の生活の中で “やるべきこと”をこ な寸際，時計の秒針や今が何年であるかということを意識し ないことも多く，これらを気にしなくても大きな問題を生じ ることが少ないからであろう。確かに, 秒単位に意識を向け なくてはならないような，陸上競技，競泳などのスポーツや 料理も存在するが, 我々の日々の生活の大半は, せいぜい短 くても分単位であると考えられる。

今後，秒単位の記録を競う競技に従事しているアスリート を対象にして, 時間単位の心理的親近性, 特に「秒」という 単位に対する親近性が，今回の結果とどの程度異なっている かどうか検討してみたい。また, 時間の感じ方が異なると言 われている, 子ども, 高齢者, 精神障害者や発達障害者の時 間単位の心理的親近性についても検討してみたい。

\section{引用文献}

Meck, W. H. (2005). Neuropsychology of timing and time perception. Brain and Cognition, 58, 1-8.

森田麻登（2012）。抑うつ傾向と感情価が心理的時間に及ほ

す影響 パーソナリティ研究，20，167-178. 